(1913-1916 гг.) // Вестник Адыгейского государственного университета. Серия 1: Регионоведение: философия, история, социология, юриспруденция, политология, культурология. 2013. № 2 (118). С. 222-227.

33. Домбровский О. Быт фабричных рабочих по данным Первой всерос. гигиенической выставки, устроенной Русским Обществом охранения народного здравия в Санкт-Петербурге в 1893 году. СПб.: Типография П.П. Сойкина, 1894. 45 с.

34. Ташбекова И.Ю. Правовое регулирование деятельности фабричной инспекции в России в конце XIX - начале XX вв.: автореф. дис. ... канд. юрид. наук. М., 2006. 27 с.

35. ЦГИА СПб. Ф. 1229. Оп. 1. Д. 48.

36. Гурская В.С. Проблема организации женской фабричной инспекции в России в конце XIX - начале XX вв. // Модернизация в России: история, политика, образование: мат-лы всерос. науч. конф. с междунар. участием, 20 апреля 2015 г. Вып. 7. 2015. С. 44-47.

37. Беликов Б.Д. Женщина в промышленной инспекции запада. К вопросу о введении женской фабричной инспекции в России. Тверь: Типо-Литография М.В. Беликова, 1914. 63 с.

38. Принятие законопроекта о женщинах - фабричных инспекторах // Мир женщины. 1912. № 7-8.

39. Северцева О.В. Охрана труда женщин - фабричных работниц во второй половине XIX - начале XX вв. // Государство и право: эволюция, современное состояние, перспективы развития (навстречу 300-летию российской полиции): материалы науч.теор. конф. СПб., 2016. С. 269-272.

40. ЦГИА СПб. Ф. 1229. Оп. 1. Д. 106.

41. Российская национальная библиотека. Отдел рукописей. Ф. 341. Ед. хр. 661.

\title{
SOCIAL PROTECTION OF FEMALE WORKERS AT SAINT PETERSBURG INDUSTRIAL ENTERPRISES IN THE SECOND HALF OF THE XIX - EARLY XX CENTURY AS ONE OF THE ASPECTS OF EVERYDAY LIFE FEMALE HISTORY
}

(C) 2018

\author{
Severtseva Olga Valentinovna, lecturer of history
}

Vyborg Institute (branch) of Pushkin Leningrad State University (Vyborg, Leningrad Region, Russian Federation)

Abstract. The paper refers to the measures of social protection of female workers at St. Petersburg industrial enterprises in the second half of the XIX - early XX century. Social security is an important part of any person's everyday life, especially women. Laws adopted in the Russian Empire, within the framework of factory legislation, were aimed at supporting the interests of industrial entrepreneurs rather than female workers. Legislative acts that were supposed to guarantee social protection for women workers were practically not observed. Many of these laws were even abolished by later regulatory acts. Female workers did not receive equal wages with men. Women had to work long hours in unsanitary conditions. Female workers were almost «slaves» for the owner of an industrial enterprise. Factory inspectors could not help women workers solve their problems. The authorities did not provide social protection for women in St. Petersburg, who worked for factories in the second half of the XIX - early XX century.

Keywords: everyday life; female workers; industrial enterprises; St. Petersburg; social protection; factory legislation; working hours; salary; fines; overtime work; work-related injuries; leave for pregnancy and childcare; female factory inspection; protection of rights.

УДК 502.04 (252.51) (470.56)

Статья поступила в редакцию 14.06.2018

\section{ОПЫТ ОРГАНИЗАЦИИ СТЕПНЫХ ЗАПОВЕДНИКОВ В ЮЖНОМ ПРЕДУРАЛЬЕ В КОНЦЕ ХІХ - ПЕРВОЙ ТРЕТИ ХХ ВЕКОВ В КОНТЕКСТЕ СОВРЕМЕННЫХ ЗАДАЧ УСТОЙЧИВОГО РАЗВИТИЯ СТЕПЕЙ РОССИИ В ХХІ ВЕКЕ}

(C) 2018

\author{
Мишанина Елена Владимировна, кандидат исторических наук, \\ научный сотрудник отдела степеведения и природопользования \\ Институт степи УрО РАН (г. Оренбург, Российская Федераџия) \\ Мишанина Екатерина Вячеславовна, магистрант кафедры истории России \\ Оренбургский государственный педагогический университет (г. Оренбург, Российская Федерация)
}

Аннотаиия. В статье рассмотрена история двух степных заповедников, существовавших на территории
Ожного Предуралья (современная Оренбургская область). Первый образован А.Н. Карамзиным в частном
владении Полибино Бугурусланского уезда Самарской губернии на рубеже ХІХ-ХХ вв. Площадь его состав-
ляла 650 га, местонахождение, период существования, а также проводимая в нем научная и практическая де-
тельность оставались неизвестными. На его территории исследовались флора, фауна, велись метеорологи-
ческие наблюдения. Полученные данные опубликованы владельцем в ряде монографий. В нач. 1920-х гг. его
площадь поверглась полной распашке. Второй заповедник под названием «Козяка» открыт в Курманаев-
ском районе Средне-Волжского края стараниями директора Пензенского государственного заповедника
И.И. Спрыгина и просуществовал с 1930 по 1935 гг. Он представлял собой значительный массив целинной
степи и долговременных залежей, богатых степным биоразнообразием. Был утрачен при передаче из Средне-
Волжского края в Оренбургскую область. Изучение опыта создания степных заповедных участков имеет науч-
ное и практическое значение при их проектировании и выделении в дальнейшем с целью создания особо охра-
няемых природных территорий, а также определения охранного статуса существовавших ранее заповедников. 
Ключевые слова: биоразнообразие; Карамзин А.Н.; Карамзин Н.М.; «Козявка»; «Малая Козявка»; особоохраняемая природная территория; Оренбургская область; Полибино; Самарская губерния; сохранение целинных степей; Спрыгин И.И.; Средне-Волжский край; «Степная пустошь»; степной заповедник; степная гадюка; степь; сурок; Уранов А.А.

В современном мире сохранение целинных степей является одним из приоритетных направлений природоохранной деятельности. В связи с этим изучение опыта предшественников по созданию степных заповедников - актуальная задача, решение которой позволяет изучить не только историю проводимых мероприятий по сохранению степей в XIXXX вв., а также получить бесценный опыт и шанс избежать просчетов в этой деятельности в контексте современных задач устойчивого развития степей в текущем столетии. В современной историографии, посвященной первым российским заповедникам рубежа XIX-XX вв. упоминается о существовании в имении А.Н. Карамзина, частного владельца Самарской губернии, степного заповедника, площадью 600 десятин $[1$, с. $11 ; 2$, с. $63 ; 3$, с. 21$]$ без конкретной отсылки на источники. Единственным документальным свидетельством можно считать строку из некролога о смерти А.Н. Карамзина, опубликованную в харбинской газете «Новая жизнь» в 1927 г. Его автор, видимо из окружения А. Карамзина, скрытый под инициалами «С.Е.» упоминая о заслугах покойного, написал о создании им степного заповедника в заволжской лесостепи.

Александр Николаевич Карамзин (1850-1927), внучатый племянник историографа Н.М. Карамзина, унаследовал имение Полибино Бугурусланского уезда Самарской губернии в 1887 г. [4, с. 3] от предков, которые владели им с начала XIX в. Данное поместье располагалось в лесостепной зоне (в ее самой засушливой части) в междуречье р. Мочегай и Кисла (правые притоки р. Большой Кинель, бассейн Волги). А.Н. Карамзин вместе с братьями имел около 15000 дес. (16400 га). Часть целинных земель под названием «Степная пустошь», принадлежавших А.Н. Карамзину, располагалась к югу и юго-востоку от с. Полибина и состояла из 7683 дес. 883 саж. (8394 га). Биография и научная деятельность Александра Николаевича Карамзина достаточно хорошо изучены [5].

В Государственном архиве Самарской области авторами выявлен межевой план Второго участка пустоши Степной с прирезанной к нему землей от дачи 1 участка с. Покровского Полибина с деревнями Ружевкой и Бестужевкой. Обмежеван в 1851 г., вторично с прирезанными участками земли в 1878 г., владение ротмистра А.А. Карамзина [6; 7]. Общее количество десятин земли 7683 дес. 883 саж., или около 5380 га. Судя по литературным источникам, примерно 10\% этой земли (650 га) А.Н. Карамзин отвел под степной заповедник.

С последней четверти XIX в. до 1917 г. Полибино, благодаря своему владельцу, стало научным центром по изучению природы и климата Заволжья.

В окрестностях с. Полибина в настоящее время находятся три памятника природы, связанные с именем помещика и его деятельностью по лесоразведению: лесопарк в усадьбе А.Н. Карамзина 2,6 га, лесопосадки А.Н. Карамзина у с. Полибино 4,7 га, лесопосадки А.Н. Карамзина на Белом хуторе 32 га [4; 8]. А. Карамзин был награжден за опыты по лесораз- ведению золотой медалью Лесоохранительного комитета и ценным подарком [9, л. 1].

С 1882 по 1917 гг. исследователем при помощи энтузиастов велись регулярные измерения температуры воздуха и почвы, направлений ветра, осадков и снежного покрова. На территории поместий Карамзиных с 1882 г. действовали 5 метеостанций (Полибино, хут. Ключевский, хут. Ружевка, Козловка, хут. Тихий) [10, с. 2-3]. Из них 2 - на территории Полибина и хут. Ключевского (на расстоянии 10 верст друг от друга). В 1907 г. за труды по изучению климата А. Карамзин представлен к высочайшей награде Николаевской Главной Физической Обсерватории $[11$, л. 7$]$, итоги исследования изложены в его монографии [10].

На протяжении 30 с лишним лет А.Н. Карамзин изучал орнитофауну в своем поместье и сопредельных территориях, результаты представлены в монографии [12].

Из 248 видов птиц, наблюдаемых ученым, 167 видов были встречены и описаны в окрестностях с. Полибина, на степных участках около усадьбы изучен 21 степной вид, среди них Aegypius monachus, Gyps fulvus, Tetrax tetrax, Otis tarda. В начале 1917 г. коллекцию «из 500 шкурок» птиц А. Карамзин отправил в дар Зоологическому музею в г. Санкт-Петербурге.

Кроме лесоразведения на территории проводились ботанические исследования. Супруга А.Н. Карамзина Екатерина Васильевна собрала 17 образцов растений, вошедших в гербарий В.Я. Цингера и опубликованный С.И. Коржинским в 1893 г. [13]. Из немногих сведений о гербарных образцах, можно заключить, что сборы проводились в различных типах местообитаний. Среди видов присутствуют степные (Clausia aprica (Steph.) Korn.-Tr., один из видов Alyssum (по-видимому, ошибочно идентифицированный как Alyssum alpestre L.), Crambe tataria Sebeok, лесные (Anemone ranunculoides L., Delphinium elatum L., Corydalis solida (L.) Clairv., Aconitum lycoctonum L. (A. septentrionale Koelle)), произрастающие по лугам, берегам и в прибрежной части водотоков и водоемов (Thalictrum minus L., Th. flavum L., Ranunculus auricomus L., Ranunculus acris L., Trollius europaeus L.), в воде (Numphar lutea (L.) Sm.), а также сорные (Consolida regalis Gray, Barbarea vulgaris R.Br., Sisymbrium loeselii L., Chorispora tenella (Pall.) DC.).

Некоторые из указанных видов относятся ныне к редким и занесены в Красную книгу Оренбургской области (2014): Clausia aprica (Steph.) Korn.-Tr., Crambe tataria Sebeok.

Кроме того, в окрестностях с. Полибина А. Карамзиным были обнаружены останки ископаемых рыб, которые переданы в 1910 г. Геологическому музею Академии наук в Санкт-Петербурге [14, с. 61].

Таким образом, можно констатировать не только факт наличия в имении А.Н. Карамзина земельного целинного участка, подходящего для создания степного заповедника, но и проведение владельцем значительной разноплановой научной работы по изучению природы с публикацией полученных научных результатов. 
«Степная пустошь» была практически полностью распахана в первое трехлетие после окончания Гражданской войны на территории Самарской губернии. К 1923 г. относятся попытки закрепить национализированные распаханные «удобные» участки и «разверстать» их за близлежащими селами [15].

Современные методы исследования дают возможность определить наличие сохранившихся целинных участков на исследуемой территории. При совмещении плана «Степной пустоши» с космоснимками очевидна практически сплошная распашка указанной территории. На основе данных дистанционного зондирования определено, что степь сохранилась, вероятно, на 4 небольших участках, которые представляют собой овраги и неудобья.

Следующий эксперимент создания степных заповедников пришелся на конец 1920-х гг. Это время в СССР характеризуется пристальным вниманием советских ученых к проблемам охраны степей, распахиваемых в первые годы советской власти активно и бесконтрольно. В письме Государственного комитета по охране природы в междуведомственную комиссию по охране природы от 20.02.1929 г. указывалось: «Вопрос о сохранении целинных степей имеет громадное научное и практическое значение. Ввиду быстрой распашки степей необходимо принять экстренные меры к их охране» [16, л. 5].

К приложенной к письму выписке из протокола № 1 от 8 января 1929 г. [16, л. 6] заседания Президиума Государственного комитета по охране природы, подписанном председателем Н.М. Кулагиным и ученым секретарем С.А. Северцовым содержалась программа спасения целинных степей. На заседании были заслушаны доклады профессора Б.А. Келлера о степях Центрально-Черноземного округа и профессора И.И. Спрыгина о степях Средне-Волжской области. Президиум констатировал, что целинных степей в указанных регионах «осталось крайне мало». Сохранились в Центрально-Черноземном округе -8 участков от 150 до 1500 га, в общей сложности 4900 га «что к первоначальному количеству целинных степей представляется крайне незначительным. Оставшиеся участки степей имеют огромную ценность как памятники природы, их сохранение совершенно необходимо для изучения естественных свойств и эволюции черноземных почв при разрешении проблем, связанных с повышением урожайности страны» [16, л. 6].

Для чего президиум Госкомитета предложил поставить перед соответствующими организациями, в частности Народным комиссариатом земледелия и исполкомами Центрального Черноземного округа, Средне-Волжской области, Нижне-Волжской области, Калмыцкой автономной области, СевероКавказского края и Уральской областей, вопрос об охране сохранившихся степей. В первую очередь прекращение распашки целинных степей, выявленных обследованием, согласно прилагаемым спискам, часть выявленных участков обратить в полные и частичные заповедники.

«При образовании этих заповедников Президиум считает целесообразным выделить и представить на утверждение Совнаркома РСФСР не менее 4 крупных степных заповедников: один в ЦентральноЧерноземном округе, один в Северо-Кавказском крае, один в Средне-Волжской области и один в Нижне-Волжской области с тем, чтобы эти заповедники по размерам своей территории могли сохранить не только флору, но и частично фауну целинной степи. К этим крупным заповедникам привязать мелкие участки целинной степи и реликтовой растительности согласно вышеупомянутым спискам. Эти местные участки обратить в заповедники в порядке п. 5. Постановления СНК от 6.10.1925 г. «Об охране природы». При образовании заповедников считать необходимым некоторые части их объявить заповедниками полными, остальные же части заповедниками частичными, запретив распахивание степи и допустив выпас скота и сенокоса в размерах, гарантирующих сохранение степи». Предлагалось также обратить внимание научных учреждений и органов по охране природы на необходимость дальнейшего выявления участков целинной степи. Для проведения вышеуказанных мероприятий в жизнь «просить Главнауку в срочном порядке запросить с мест дополнительные материалы, планы и описания участков» $[16$, л. 6].

В протоколе также отмечалось, что экспедицией под руководством профессора И.И. Спрыгина намечено образование заповедников на участках целинной степи в Средне-Волжском крае. Под п. 10 [16, л. 5] значилась ««Степь Козявка» в южной части Бузулукского уезда на границе с Казахстаном, (бывшая Уральская область), (в 90 км к ЮЮВ от г. Бузулука и в 75 км от станции Погромной Ташкентской ж.д. $52^{\circ}$ с.ш. и $21^{\circ} 75^{\prime}$ в.д.). Степь эта расположена на довольно сильно всхолмленном плато северной части Общего Сырта. Площадь участка 1364,61 га. Небольшие речки и долы частью ограничивающие участок, частью прорезывающие его территорию, в летнее время без воды. Почвы (по работе С.С. Неустроева, Л.И. Прасолова и А.И. Бессонова) [17] представляют тяжелые, бедные черноземом, но большая площадь, приблизительно $2 / 5$ участка заняты почвами засоленными. Под несомненной степью на участке «Козявка» находится приблизительно 1/2 площади, остальная представляет залежи. Растительные ассоциации, слагающие целину, грубо могут быть разделены на три группы: 1) степь с господством... (так в тексте, латинское название пропущено при печати - прим. авторов); 2) редкая кочковатая степь на засоленных почвах; 3) степь северного типа, более влажная с господством...и другими ковылями в несколько пониженных местах на плато, где также сосредотачиваются и заросли степных кустарников. В небольших количествах В.И. Баженовым обнаружен в степи сурок. Из списка животных, представленных мне этим зоологом, видно, что животный мир достаточно разнообразен и богат в видовом отношении. Млекопитающих в списке имеется 28 видов. Наиболее замечательными кроме сурка являются пищуха, степная гадюка» [16, л. 5].

В протокол включены данные экспедиции за 1928 г. под руководством И.И. Спрыгина [16, л. 5] совместно с А.А. Урановым на участке сухой степи в полосе по северному склону Общего Сырта к южному колену р. Бузулук, которая «выявила к югу от с. Ефимовки (современньй Курманаевский район Оренбургской области - прим. авт.) при плакорных условиях две группировки, вполне оправдывающие 
отнесение этого района к зоне сухих степей. Одна из них, на солонцеватых почвах, представляла ассоциацию с господством Festuca sulcata, Stipa capillata и Artemisia maritima, сопровождавшихся немногочисленными формами, как Agropyrum ramosum, Aster villosus, Ornithogalum narbonense, Pyrethrum achilleaefolium и др. Другая, менее распространенная, так как, повидимому, в главной своей площади уже была распахана, представляла ковыльную степь с господством Stipa Lessingiana, Festuca sulcata u Agropyrum ramosum, также бедную, но типичную по видовому составу (37 видов) степь с Aster villosus, Jurinea linearifolia, Ornithogalum narbonense, Allium albidum и др. Характерно, что встреченные здесь ассоциации более северного типа, с ковылями S. rubens, S. ioannis, S. dasyphylla и S. stenophylla, как и заросли степных кустарников (Cytisus ruthenicus, Spiraea crenifolia, Prunus fruticosa) были приурочены в водораздельной части участка к заметным, хотя и мало опущенным западинам, легким ложбинам и долкам, чем подчеркивается южный характер условий, в которых находится здесь растительный покров» [18, с. 89].

Таким образом, в 1928 г. земли проектные под заповедник составляли целинные и разновременные залежи, расположенные между пахотными полями, принадлежавшими совхозу «Скотовод», в планы которого явно не входило выделение 1364 га из землепользования. По результатам экспедиции началась почти двухлетняя переписка о включении участка в состав Средне-Волжского государственного заповедника. ««Скотовод» категорически протестовал и протестует по передаче участка под заповедник, поскольку он находится в центре массива» - писал в Крайисполком 26.09.1930 г. М. Иванцов - заместитель заведующего краевым земельным управлением $[19$, л. 2]. Но, тем не менее, в октябре 1930 г. в письме в несколько адресов: начальнику Андреевской землеустроительной зембригады Андреевского РИКа, директору Любимовского мясосовхоза, уполномоченному Скотоводтреста, начальнику Самарского землеустроительного района М. Иванцов сообщал следующее: «В отмену всех ранее данных распоряжений предлагается заповедник «Козявка», расположенный в Любимовском массиве совхоза «Скотовод», довести до площади как минимум 1000 га. После отвода земли в натуре, передать участок представителю госзаповедника. Предложить мясосовхозу указанный участок не распахивать и скот на нем не пасти. В виду того, что участок «Козявка» расположен в центре Любимовского массива «Скотовод», необходимо обязать госзаповедник огородить участок (живой изгородью или проволокой). На первое время разрешается сделать кругом участка канаву глубиной не менее одного метра» [19, л. 3].

Интерес ученых изначально представляли два участка «Козявка» (восточный 765,65 га) и «Козявка Малая» (западный 598,35 га). «Малая Козявка» резервировалась совхозом под выгонные земли для развития овцеводческого хозяйства. Участок граничил с запада с участком ГЗИ (государственных земельных имуществ) «Ветляным», с севера «Барханы», с востока «Козявка», с юга «Иловым» и землями п. Землероб [20, л. 5]. Но именно на этом участке сохранились степи с господством Stipa Lessingiana и еще «два естественно-исторических объекта, отсут- ствующие в восточной части (на участке собственно «Козявка»)» а именно: «Большой участок злостных солонцов с большими пятнами, почти свободными от растительности, но содержащими весьма характерные формы солончаковых растений; 2. зоолог экспедиции Ваганов выявил жилые норы сурка, почти исчезнувшего в Волжской области; 3. 80\% из 765 га заняты столбчатым солонцом с господством ковыляволосатика (Spira caillata) и полыни (Artemisia maritinna) [20, л. 6 об.].

Участок «Козявка» (765 га) находился в Андреевском районе Самарского округа и граничил с запада участком ГЗИ «Малая Козявка», с севера участком ГЗИ «Барханы», с востока - с участком ГЗИ «Лабазинским» и землями п. Новосельцева, с юга - с землями п. Киреевского и участком ГЗИ «Иловым» приблизительно на $53^{\circ} 41^{\prime}$ с.ш. и $20^{\circ} 15^{\prime}$ в.д. [21, л. 6].

В 1928 г. экспедицией И. Спрыгина также обследовался Бузулукский бор, который в 1930 г. включен в проект заповедников, в августе 1932 г. в состав заповедного участка Средне-Волжского заповедника. В этом статусе просуществовал до 15 марта 1936 г. С разделением Средне-Волжского края на Куйбышевский край и Оренбургскую область, вошел в состав Оренбургской области [22, л. 10].

В докладной записке о Пензенских заповедниках, датированной 1938 г. сообщалось, что «При разделении Куйбышевского края на Куйбышевскую и Оренбургскую область заповедники, находящиеся на территории последней «Бузулукский бор» и степь «Козявка» были выделены в самостоятельный бюджетный заповедник» [23]. Но в документах об организации и деятельности заповедника «Бузулукский бор» за 1936-1949 гг. сведений о включении заповедника «Козявка» и его деятельности не имеется. Таким образом, время существования «Козявки» определяется периодом с 1930 по 1935 гг. При переводе заповедника из одной области в другую он, видимо, намеренно потерялся. Какие-либо документы о деятельности и сотрудниках данного заповедника в региональных архивах Самарской и Оренбургской областей выявить не удалось.

5 мая 2016 г. экспедицией под руководством С.А. Сенатора предпринималась попытка определения современного состояния заповедника «Козявка». Но по грунтовым дорогам, разъезженным нефтяниками, экспедиция не смогла проехать к данному участку. «Повсюду виднелись распаханные поля и зеленые посевы. Вероятно, Козявку занимают ныне сельскохозяйственные угодья»- сделали заключение участники экспедиции [24, с. 224].

Пензенские исследователи Т.В. Горбушина и Л.А. Новикова считают, что «степь «Козявка» характеризуется большой ценностью как растительного, так и животного мира степей. Присутствие на ней большого числа засоленных участков, не пригодных для распашки, дает ей большие шансы сохраниться до настоящего времени. Желательно организовать поиск и детальное изучение этого участка» [23, c. 353].

Согласно сохранившимся картам «Козявки» [23] при совмещении их с космоснимками определяется местоположение бывшего заповедника в 10,2 км к югу от южной окраины с. Ефимовки Курманаевского района Оренбургской области. Около $2 / 3$ территории 
Мишанина Е.В., Мишанина Е.В.

на сегодняшний день активно распахивается, часть (около 500 га) не пахалась или частично подвергалась распашке ранее, но в настоящее время представляет степь и долговременную залежь, поросшую местами кустарником. Эта территория ограничена с запада и юго-запада правобережным оврагом р. Бузулук Большой Дол, с востока - полевой дорогой из с. Ефимовки, с севера - правым ответшком оврага Большой Дол. С юго-запада на северо-восток территорию пересекает коридор коммуникаций нефтяников и идущая параллельно ему полевая дорога. По сохранившимся описаниям данный участок тяготеет к участку «Малая Козявка». Наземная верификация данных проведена 04.05.2017 г. Проезд к месту осуществлен с востока со стороны с. Нововасильевка Курманаевского района по заброшенной и практически полностью запаханной дороге. Видимо, И. Спрыгин добирался тем же маршрутом, так как нами встречены три курганообразных холма, описанных им в полевом дневнике на подъезде к участку. Хотя степь «Козявка» не полностью сохранилась в целинном виде, однако некоторые ее участки представляют собой типичные зональные степные сообщества, сохранение которых целесообразно в связи со значительной нарушенностью как территории района, так и степной зоны в целом.

Помимо хорошо развитых и малонарушенных ковыльных степей, в составе которых встречаются обычные степные виды (Galatella villosa (L.) Rchb. f., Galium ruthenicum Willd., Valeriana tuberosa L., Astragalus testiculatus Pall. и др.), здесь присутствуют фитоценозы с преобладанием Artemisia nitrosa Weber ex Stechm, представляющие собой галофитный вариант зональной растительности.

Широкое распространение тырсовых (Stipa capillata) степей, а также значительное обилие Artemisia austriaca Jacq. указывает на интенсивный выпас в прошлом. В настоящее время какого-либо антропогенного воздействия на степь не оказывается.

Поскольку раритетные степные участки представляют интерес в историческом и научных аспектах, возникает необходимость их сохранения. В перспективе территорию двух бывших степных заповедников «Карамзинская степь» и «Козявка», целесообразно включить в список ООПТ Оренбургской области с приданием им статуса историко-ботанических памятников природы. При стремительном сокращении степных пространств в Южном Предуралье указанные мероприятия позволят сохранить и изучить не только отдельные степные территории, но и способствовать устойчивому развитию степного региона в целом.

\section{Список литературы:}

1. Насимович А.А. Дореволюционный период в развитии заповедного дела // Опыт работы и задачи заповедников. М.: Изд-во «Наука», 1979. С. 7-20.

2. Чибилев А.А. Степям нужен заповедник // Природа и мы. Челябинск, 1980. С. 61-75.

3. Штильмарк Ф.Р. Историография российских заповедников (1895-1995). М.: ТОО «Логота», 1996. $340 \mathrm{c.}$

4. Карамзин А.Н. Лесоразведение в с. Полибине, Бугурусланского уезда, Самарской губернии. 33 с. текста, таблица, карты, 33 фото. СПб., Голике и Вильборг, 1913. 33 с.
5. Мишанина Е.В. Научная и практическая деятельность А.Н. Карамзина по восстановлению и разведению леса в лесостепном Заволжье в конце XIX начале ХХ вв. // Аридные экосистемы. 2011. № 3 (48). C. 91-95.

6. Государственный архив Самарской области (ГАСО). Ф. 388. Оп. 3. Д. 2575.

7. ГАСО. Ф. 388. Оп. 38. Д. 255.

8. Природное наследие Оренбургской области: особо охраняемые природные территории. Оренбург. Печатный дом «Димур», 2009. С. 86-89.

9. ГАСО. Ф. 387. Оп. 1. Д. 1372.

10. Карамзин А.Н. Климат Бугурусланского уезда, Самарской губернии. Самара. Тип. Губ. земства, 1912. 1024 c.

11. ГАСО. Ф. 430. Оп. 1. Д. 2050.

12. Карамзин А.Н. Птицы Бугурусланского и сопредельных с ним частей Бугульминского, Бузулукского уездов Самарской губернии и Белебейского уезда Уфимской губернии // Мат-лы к позн. фауны и флоры Российской имп., отд. зоолог. 1901. Вып. 5. C. 203-394.

13. Коржинский С.И. Флора Востока Европейской России в ее систематическом и географическом отношениях // Изв. Томск. ун-та. 1893. Кн. 5. С. 71299.

14. Русскин Г.А. Действительный член Русского Географического общества Карамзин Александр Николаевич // Известия Оренбургского отделения русского географического общества. 2005. № 1 (34). C. 58-62.

15. Государственный архив Оренбургской области (ГАОО). Ф. 44. Оп. 1. Д. 61.

16. ГАСО. Ф. 558. Оп. 1. Д. 211.

17. Неустроев С.С., Прасолов Л.И., Безсонов А.И. Естественные районы Самарской губернии. СПб.: Изд. Самарского губ. зем., 1910. 91 с.

18. Спрыгин И.И. Растительный покров Средневолжского края // Самарская Лука: проблемы региональной и глобальной экологии. 2013. Т. 22, № 3. C. 32-112.

19. ГАСО. Ф. 779. Оп. 2. Д. 641.

20. ГАСО. Ф. 779. Оп. 2. Д. 596.

21. ГАСО. Ф. 779. Оп. 2. Д. 733.

22. Бугурусланский филиал Государственного архива Оренбургской области. Ф. 846. Оп. 1. Д. 246.

23. Горбушина Т.В., Новикова Л.А. Судьба заповедного участка «Козявка» (Оренбургская область) // Современные концепции экологии биосистем и их роль в решении проблем сохранения природы и природопользования: мат. всерос. (с междунар. участием) науч. школы-конф., посв. 115-летию со дня рожд. А.А. Уранова. Пенза, 2016. С. 350-353.

24. Головлев А.А., Саксонов С.В. Совместная научная экспедиция Русского ботанического общества и Русского географического общества в Самарской, Саратовской и Оренбургской областях // Самарская Лука: проблемы региональной и глобальной экологии. 2016. Т. 25, № 4. С. 218-225.

Статья подготовлена по теме НИР «Степи России: ландшафтно-экологические основы устойчивого развития, обоснование природоподобных технологий в условиях природных и антропогенных изменений окружающей среды” № PГ $А A A A-$ A17-117012610022-5. 


\section{THE EXPERIENCE OF STEPPE RESERVE ORGANIZING IN SOUTHERN PRE-URALS \\ IN THE LATE XIX - THE FIRST THIRD OF THE XX CENTURY AND THE PROBLEM OF RUSSIAN STEPPES SUSTAINABLE DEVELOPMENT OF THE XXI CENTURY}

(C) 2018

Mishanina Elena Vladimirovna, candidate of historical sciences, researcher of Steppe Science and Nature Management Department

Institute of Steppe of the Ural Branch of the Russian Academy of Sciences (Orenburg, Russian Federation) Mishanina Ekaterina Vyacheslavovna, master student of History of Russia Department Orenburg State Pedagogical University (Orenburg, Russian Federation)

\footnotetext{
Abstract. The article analyzes the history of two steppe reserves in the territory of the Southern Urals (Orenburg region nowadays). The first one was established by A.N. Karamzin in private grounds of Polibino, in Buguruslan Uyezd of Samara Region (Gubernia), in 19-20th centuries. Its area was 650 hectares, while its location, period of its existence, as well as the scientific and practical activities remained unknown. Flora and fauna as well as meteorological observations were conducted in this place. The results of the researches were published by the owner in a number of monographs. In early 1920's this area was totally changed. The second reserve named «Koziavka» was opened in Kurmanaevsky District of the Middle Volga Region by I. Sprygin, with the help of the director of Penza State Reserve that existed from 1930 to 1935. It was a significant area of virgin steppe and long-term fallow land with rich steppe biodiversity. It was lost during the land transfer reform - from the Middle Volga Region to Orenburg Oblast. Similar reseraches have a practical significance. That will help to design and find these sites with further transformation into specially protected natural areas, as well as to determine the conservation status of previously existing reserves.

Keywords: biodiversity; Karamzin A.N.; Karamzin N.M.; «Koziavka»; «Malaya Koziavka»; specially protected natural area; Orenburg Oblast; Polibino; Samara Gubernia; virgin steppe conservation; Sprygin I.I.; Middle Volga Region; «Steppe Pustosh»; steppe reserve; east steppe viper; steppe; marmot; Uranov A.A.
} 